\title{
索状能動体に関する研究 ーシステムの自立化と対地適応推進一
}

遠 藤 玄* 外川圭 司* 広 瀬 茂 男 ${ }^{*}$

\section{Study on Self-Contained and Terrain Adaptive Active Cord Mechanism}

\author{
Gen Endo*, Keiji Togawa* and Shigeo Hirose*
}

\begin{abstract}
A snake is able to attain high terrain adaptability and versatile locomotion even though it has an extremely simple onedimensional configuration. In order to utilize these functions for robotics, we have adapted the basic biological machine elements of the snake into the Active Cord Mechanism (ACM). And we have discussed about the creeping dynamics and applications to manipulation. In this paper, we developed a new experimental model named "ACM-R1" with a selfcontained system, which realizes higher mobility and terrain adaptability compared with a past model. Next, gliding experiments on ice were carried out in order to demonstrate that the creeping motion is the same as the principle of skating. Finally, a new terrain adaptive control method for sloping surfaces is proposed, and we verified the effectiveness by slope climbing experiments.
\end{abstract}

Key Words: Snake-like Robot, Active Cord Mechanism (ACM), Creeping Locomotion

\section{1. はじめに}

ヘビは一次元的で単純な形態でありながら,高い移動機能と環 境への適応性を獲得している。このような汎用的で多彩な機能を 工学的に応用することは非常に有用である.筆者らはへビの生物 機械としての要素を抽出した概念を“Active Cord Mechanism, $\mathrm{ACM}$ ”と呼び, その移動方式の力学的検討やマニピュレーション への応用を論じてきた。

特に移動方式に関してはへビの典型的な推進であるほふく滑走 の解析を行い, 動物実験と比較検討した。また機械モデル“ACM III”を構築し，二次元平面上での推進運動を実現した[1].

しかしながら過去の機械モデルでの検証は,ほふく推進運動の 定性的な確認にとどまっており, 定量的な考察の多くは未だなさ れていない.また研究動機そのものも生物機械としてのへビをバ イオメカニクスの立場から科学的に明らかにするという観点から 生じており,ほふく推進そのものの工学的応用に対する議論は行 われていなかった.

そこで本研究ではアクチュエータ出力や機構的拘束など, 機械 モデルを駆動する上で必然的に生ずる枠組みを第一義的に考え， それに適用しうる有用な運動制御法を構築していく立場をとるも のとする.そして索状能動体としての効率的, 対地適応的な移動 制御法を提案し, 実験的に検討していくことにする。

原稿受付 1999 年 4 月 26 日

·東京工業大学工学部

- Tokyo Institute of Technology
本論文では従来のモデル以上に,より自由で広範囲の移動を実 現する新たな実験機として完全自立型索状能動体“ACM-R1”の 開発を行う.またへビのほふく滑走が原理的にスケートによる滑 走と等価であることを示すため, 水上での滑走実験を行う.最後 に滑走面の傾斜に応じてくねりを制御する対地適応的推進を提案 し，その実証を行う。

\section{2. 滑 走 理 論}

ヘビの腹部側部は鱗に被われて滑りやすく,また推進運動をし ようと力を入れるとスキーのエッジのように角ができ滑走時に体 幹が法線方向にずれていくのを防ぐ.つまりへビは体軸方向には 滑りやすく法線方向には滑りにくいという摩擦特性を得ており， それが体側筋肉の収縮弛緩運動を体の軸に沿った川の流れのよう な推進運動に変換している。理論の詳細は文献[1]に譲り,ここ では本研究に関係する事項の概略のみを示す.

体軸とそれに直交する方向をそれぞれ接線, 法線方向と定め, Fig. 1 に記号を示す。従来の滑走理論は簡単のため（1）体幹を 連続体で表現 (2) 滑走体型とトルク分布は独立 (3) 静力学関係 のみを検討（4）体幹は法線方向に滑りを生じない, という前提 の下に解析を行っている.これらの仮定は厳密には満たされてお らず，動力学を含めた馬らの解析もある[2][3].

ヘビの滑走体型を表す関数としてサーペノイド曲線を仮定す る.これは体軸座標 $s に$ 沿って曲率が正弦波状に変化する曲線で

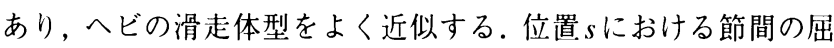
曲角度を偏角 $\theta(s)$ と表すと最大偏角を $A$, 滑走体型の $1 / 4$ 周期の 
体幹長さをlとして

$$
\theta(s)=A \sin \left(\frac{\pi}{2} \cdot \frac{s}{l}\right)
$$

Fig. 1 の $\mathrm{O}$ 点 $(\mathrm{s}=0)$ から $\mathrm{P}$ 点 $(s=l)$ までの積分值をくねり 角 $\alpha$ と定義すると, $\delta s を$ 単位節長さとして

$$
\alpha=\frac{l}{\delta s} \cdot \frac{2}{\pi} \cdot A
$$

となる。

体軸方向の速度 $V_{s}$ は, スリップが生じないと仮定することによ

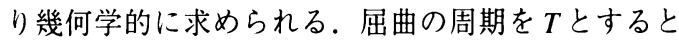

$$
V_{s}=\frac{4 l}{T}
$$

推進方向速度 $V_{X}$ は，lを推進方向 $X$ に投影した長さ $X(l)$ と $l$ との 比である行程比を用いて表される。

$$
V_{x}=V_{s} \cdot \frac{X(l)}{l}
$$

また滑走の効率を特徵づける式として接線力と法線力の比を求 めると次式が得られる.

$$
\frac{F_{t}}{F_{n}}=\operatorname{Serp}(\sigma) \cdot \alpha
$$

ここで $\sigma$ は, 筋肉の作動状態に対する定性的考察から推定され る体幹卜ルク分布を特徴づけるパラメータ, $\operatorname{Serp}(\sigma)$ は次式で表さ れる定数である。

$$
\operatorname{Serp}(\sigma) \equiv\left(\frac{2}{\pi}\right)^{\sigma} \int_{0}^{\frac{\pi}{2}} x^{\sigma-1} \sin x d x, \quad \sigma>1
$$

式（5）から，より大きな蛇行になるほど接線方向へ力が配分さ れることを示している. 法線力分布はトルク分布の 2 階微分のみ から導かれ滑走体型に依存しない．体軸に沿って描くとO点で 最大值となる概形をとる (Fig. 1).

また体幹が法線方向にスリップせずに推進を行う必要条件は

$$
\alpha \geq \frac{1}{\operatorname{Serp}(\sigma)} \cdot \frac{\mu_{t}}{\mu_{n}} \equiv \alpha_{0}
$$

で与えられ,接線方向と法線方向の摩擦係数比に依存してくねり

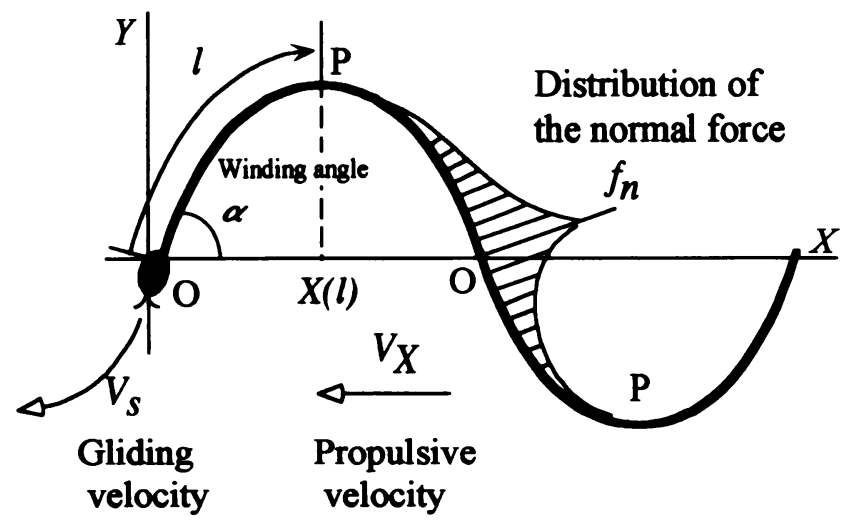

Fig. 1 Nomenclature of gliding configuration in regular creeping motion
角の下限值が規定される。

\section{3. 自立索状能動体“ACM-R1”の開発}

本章ではへビのほふく推進を実現する機械モデルとして完全自 立型索状能動体“ACM-R1”を構成する[4].

\section{1 機構}

ヘビ体幹を機械モデルで表現するには, 屈曲運動を行う能動関 節をシリアルリンク系で連結する構造が適当であると思われる. これはへビ体幹が春椎骨とそれに付属する拮抗筋群からなる筋骨 格系であることに対応している.節数は現実的に構成しうる大き さと離散化誤差の影響, および制御計算機の都合などを考慮して 全 16 節とした。

最も基本的な推進として二次元平面上での推進を考えると，ほ ふく運動のための屈曲自由度は滑走平面に対して垂直な軸周りの みとなる.Fig. 2 に示すように直鎖状に連結された関節に推進に 必要な摩擦特性を付加するため, 転がり方向に回転自在な受動車 輪を装備する。このとき離散化の影響と車輪の干涉を考慮して, 常に節の屈曲角度の半分の位置に車軸を調節する機構を導入し た。関節の可動範囲は土 $35[\mathrm{deg}]$ である。

各節は機構的に同等のユニットで構成されており,節間はコイ ルスプリングによるサスペンションが導入されている.これによ り各節にかかる荷重を均等化するとともに, 走行路面の凹凸に対 する対地適応性を向上させている（Fig. 3).

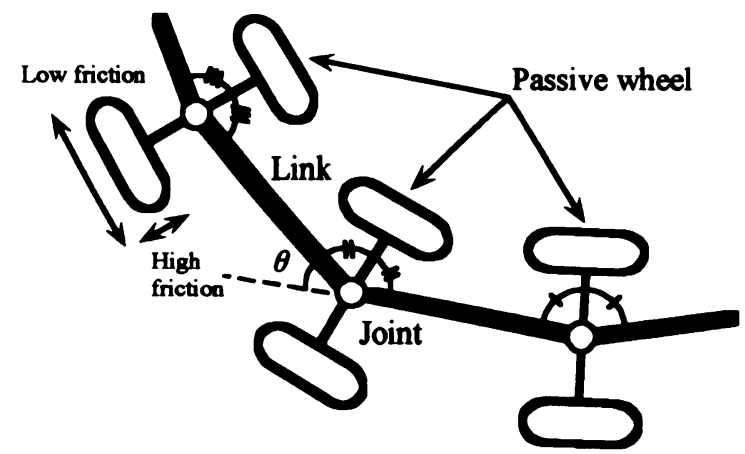

Fig. 2 Kinematic model

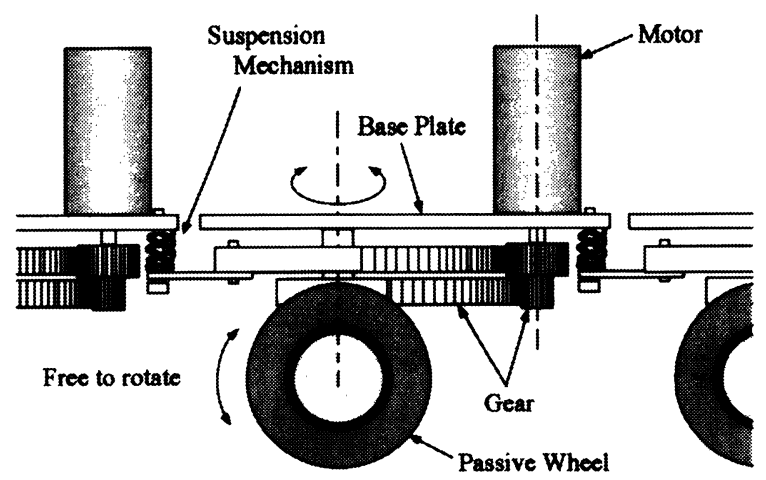

Fig. 3 Mechanism of one unit 


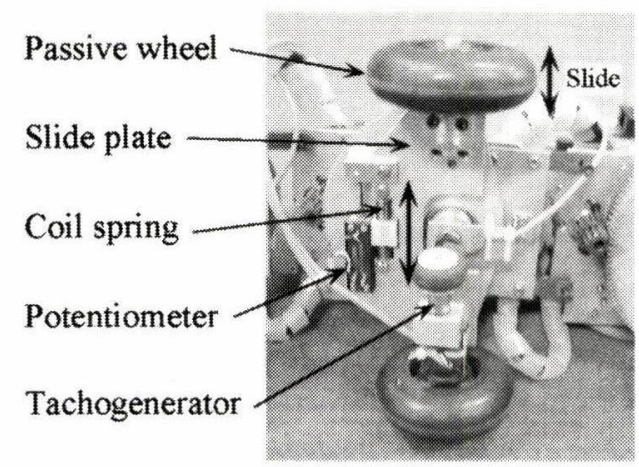

Fig. 4 Bottom view of the sensor installed joint

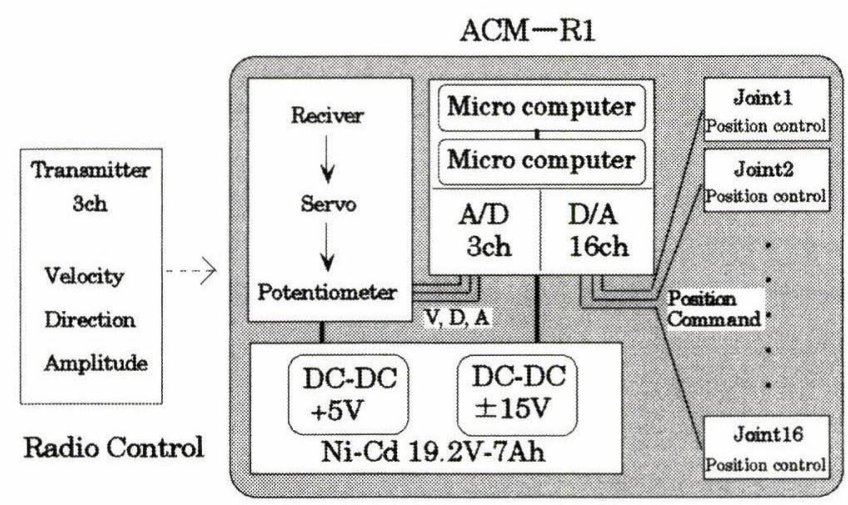

Fig. 5 Configuration of the control system

\section{2 センサ}

定常滑走時の走行状態を見るために法線力, 体軸方向速度, 関 節トルクを計測する。センサ系の概観を Fig. 4 に示す。法線力七 ンサは,リニアガイドにより車軸方向にスライド可能なプレート とコイルスプリング, ポテンショメータで構成されている. 受動 車輪を取り付けたスライドプレートをコイルバネで支えること で, 法線力を変位としてポテンショメータで計測する。また体軸 方向速度は小型の測定輪を用いてタコジェネレータにより計測す る.さらに拉およその関節トルクを測定するため, モータコイル に流れる電流值を計測している。これらセンサを端部に影響され ない第 5,13 節に装備した。

\section{3 システム構成}

システム構成をFig. 5 に示す。まず無線により，滑走の方向， 速度, および屈曲の振幅を表すパラメータを送りここれらを元に 制御計算機で各節への角度指令值を計算する。

制御計算機の計算負荷を減らすため, 各節は Titech Robot Driver [5]によるローカルな位置制御を行うオープンループの制 御とした。計算機はPIC を用いた小型ワンボードマイコン (Parallax 社 Basic Stamp II) t 2 個使用しており，相互にシリア ル通信を行うことで指令值の演算および出力を行っている.また 本マイコンボードは実装したままPCからBASICによるプログラ 么開発が直接行えるため, 走行試験を繰り返し行いながら容易に 制御プログラムを開発することが可能である.

また対地適応的推進などセンサ系からのフィードバックを用い

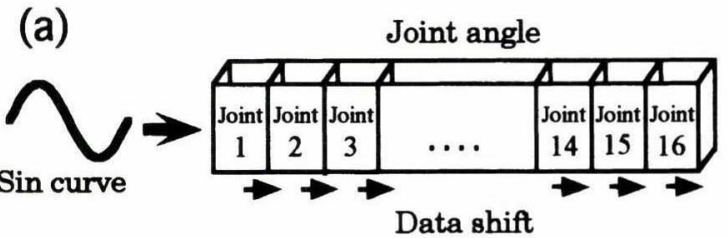

(b)

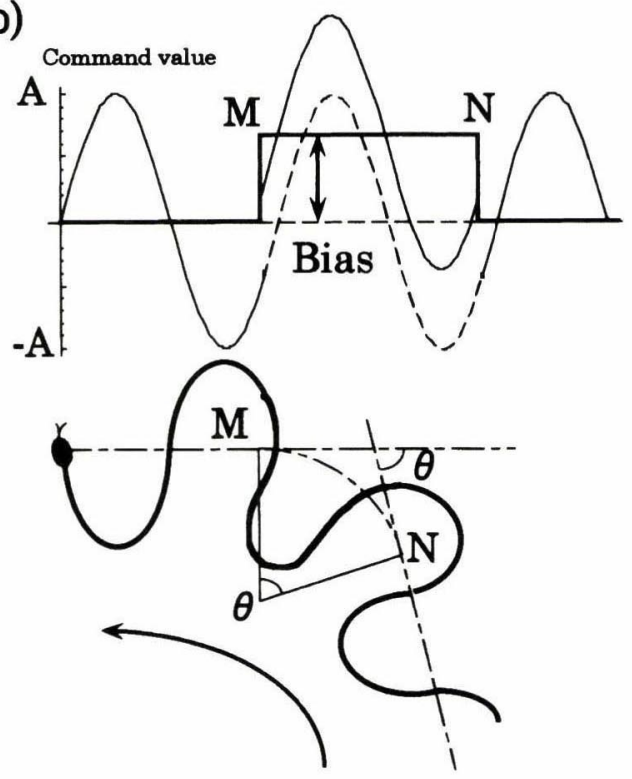

Fig. 6 (a) Control algorithm (b) Steering motion
た制御系を構筑する場合は,ソフト，ハード両面で制約の少ない 有線によるPCからの制御を行うこととした。したがって拡張性 に注意して実装した。

電源は各節に $1.2[\mathrm{~V}]-7[\mathrm{Ah}]$ の Ni-Cd電池を搭載し, これを直 列に繋ぐことで19.2[V]-7 [Ah]のバッテリーを構成している.こ の電源によりリノリューム板上でおよそ30 [min]の動作が可能で ある。また外部の電源装置からの供給もできるよう配慮した。

\section{4 制御法}

サーペノイド曲線による滑走は, 各関節角が正弦波で振動する ことから，アクチュエータの最も基本的な振動運動と考えられ る、また同時に計算負荷を著しく滅少させることが可能である.

実装された制御アルゴリズムの概念図を Fig. 6 (a)に示す。先 頭節への指令值を配列に蓄え, 順次一定時間ごとにそれを後方に シフトすることで蛇行運動を生成している.また推進速度の制御 は,計算機上を流れる時間を実時間に対して調節することで滑走 体型を変えることなく行うことができる。

推進方向の制御は屈曲を行う正弦波指令に対してバイアスをか けることにより,振動の中心值を変化させることで奏現した。バ イアスが0のとき体幹全体の屈曲の基準は直線上になるが, 一定 バイアスが作用したときは円弧になる.したがって一見複雑な蛇 行推進運動でも通常の自動車のハンドルと同等の操作系を構成で きる (Fig. 6 (b)).

さらに滑走体型を変化させるパラメータとして, 屈曲の振幅 $A$ を変化させることが可能である. 振幅が大きくなることにより， 


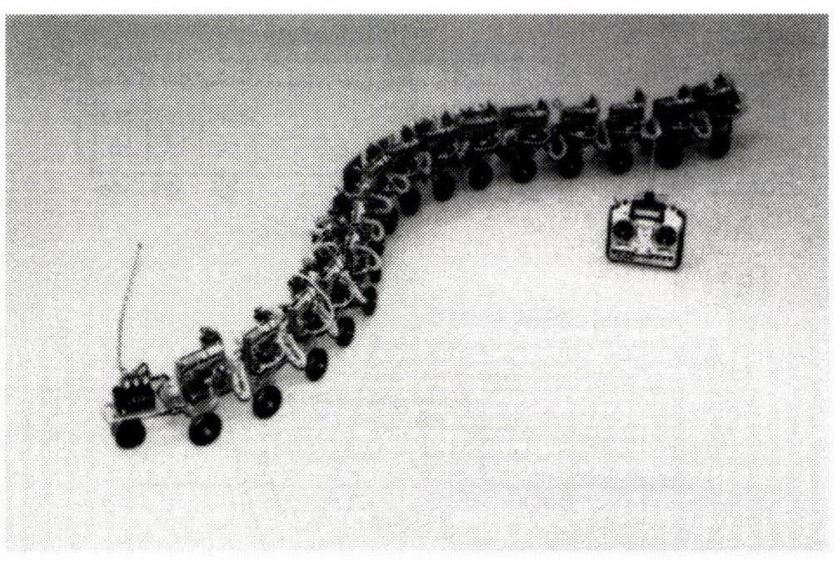

Fig. 7 ACM-R1

Table 1 Specifications of ACM-R1

\begin{tabular}{|l|r|}
\hline No. of Unit & 16 \\
\hline Dimension & $2430 \times 175 \times 220(\mathrm{~mm})$ \\
\hline Weight & $28(\mathrm{~kg})$ \\
\hline Äctuator & 50W DC Servo Motor $\times 16$ \\
\hline Battery & Ni-Cd 19.2V-7Ah \\
\hline
\end{tabular}

より大きなくねり角の蛇行を生成する（式（2））。構成された ACM-R1 を Fig. 7 に，その諸元を Table 1 に示す.

\section{4. 推 進 実 験}

構成した機械モデルが実際に滑走可能であることを確認するた め,リノリューム板上で滑走試験を行った。滑走の体型はリンク 長さと離散化の度合いを考慮して,サーペノイド曲線一周期が全 体幹長さ $L$ に相当するように $l=L / 4$ と固定し, 以降全ての実 験に用いる。

$A=22[\mathrm{deg}](\alpha=56[\mathrm{deg}]) ， T=4.2[\mathrm{~s}]$ としたとき，実測され た滑走速度は $V_{s}=0.50[\mathrm{~m} / \mathrm{s}]$ であった．理論滑走速度 $0.53[\mathrm{~m} / \mathrm{s}]$ との差異は5\%程度であり,よく一致していることが確認できる.

また周期を小さくすることでおよそ $1.0[\mathrm{~m} / \mathrm{s}]$ 程度の高速の推 進も確認した。これはACM III の $0.5[\mathrm{~m} / \mathrm{s}]$ に比して十分高速な 推進である。なお, 速度の上限はソフトウェアおよび搭載した電 源により規定されており,アクチュエータの定格出力の上限值で はない.したがってこれらを改良することにより移動速度を今後 さらに向上させることが可能であると思われる.推進速度は停止 状態から最高速まで滑走体型を変化させることなく滑らかに調節 することが可能であった。

また, ACM IIIでは実現されなかった後退の動作も，関節角指 令值を後方から前方へシフトすることで実現することができた. これは従来から一般に言われている「へビはウロコを引っかけて 進むため後退できない」という俗説への明確な反証である.

推進方向制御に関しては,バイアスを変化させることにより旋 回動作を確認した。体幹長さの 2 倍の距離があれば $90[\mathrm{deg}]$ 程度 の進行方向の変化が可能である.このことからかなり自由な操舵

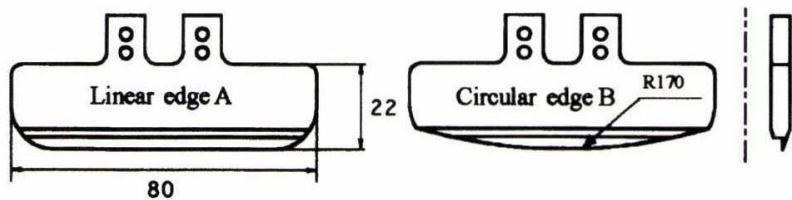

Fig. 8 Geometry of the edge A, B

Table 2 Kinetic friction coefficient

\begin{tabular}{|l|c|c|c|}
\hline & $\mu_{\mathrm{t}}$ & $\mu_{\mathrm{n}}$ & $\mu_{\mathrm{t}} / \mu_{\mathrm{n}}$ \\
\hline Edge A & 0.06 & 0.14 & 0.43 \\
\hline Edge B & 0.05 & 0.43 & 0.12 \\
\hline Wheel & 0.01 & 0.46 & 0.02 \\
\hline
\end{tabular}

が実現されていることがわかる．

さらにアスファルトや絨毯といった多少の凹凸のある路面上で の推進実験を行い, 車輪の転がり抵抗が大きな路面であっても屈 曲の振幅を調節することによって十分に推進可能であることを確 認した。

\section{5 . 水 上 滑 走}

ACM-R1 が原理的に水上でも滑走可能であることを実証する ため水上滑走試験を行った[6].

受動車輪をスケートエッジで置き換えることにより水上での滑 走を可能にする摩擦特性を付加する.摩擦倸数比による運動の違 いを検討するため 2 種類のエッジ A， B を用いて実験を行った， 外形を Fig. 8 に示す. A, B とも先は鋭く削られている. 予備 実験として2節分の重量を負荷した4枚のエッジを水上でゆっく りと滑らせ, その摩擦力を測定した。求められた摩擦係数值を受 動車輪の場合と併せて Table 2 に示す。エッジ B では水との接触 面積を極力減らすことによって接地圧を高め,水がより溶けやす くなっている。この効果により $\mu_{n}$ が $\mathrm{A} に$ 比して大きくなってい る.

$\alpha$ をおよそ55[deg]としエッジ A を装備して滑走させた。この とき横滑りを生じてその場で屈曲するのみで,ほとんど推進する ことができなかった.

次にエッジBを用いた場合, 横滑りを起こさず地上を滑走する のと同様，拈よそ $0.5[\mathrm{~m} / \mathrm{s}]$ の速度で滑らかに滑走することがで きた (Fig. 9). また受動車輪による硬平地上での滑走とまったく 同様に推進方向，速度，後退の動作などを確認した．

しかしながら人がスケートするような高速の移動は不可能で あった。これはACM-R1の場合，本体重量に比してエッジの総 接地面積が大きいため接地圧が低下し,氷が溶けにくいためであ ると思われる.その結果, 通常のスケートや受動車輪のように $\mu$ を小さくすることができず, 推進速度は遅いものとなった。より 高速な移動のためにはエッジ形状の検討やエッジそのものを加熱 するなどが必要であると思われる。

以上の実験から, 摩擦係数の差があれば水上のような非常に滑 りやすい路面であっても推進できるというほふく推進独特の特徴 


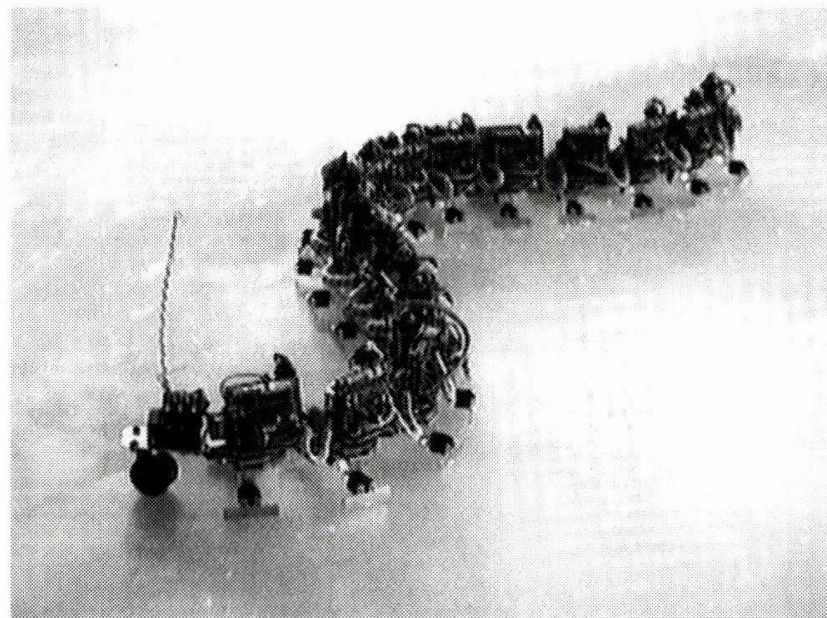

Fig. 9 Experiment on ice

が確かめられた。

\section{6. 滑走面変化に対する適応滑走}

ヘビは滑走面の摩擦係数比に応じてくねり角 $\alpha を$ 適応的に変化 させることが知られている。例えば法線方向に滑りやすい路面 や, 傾斜面の登坂のような場合では,より大きなくねり角を取る ことで接線方向に力を多く配分する.

本章ではこれを機械モデルの制御則として導入し,滑走路面の 変化に適応させることを考える.しかし摩擦係数を自由に変化さ せて実験することは難しいことから, 滑走面変化の一例として今 回は傾斜面を登坂させることを考える.これは摩擦係数比を変化 させた場合と等価的に考えることができる。また適応推進の評価 基準としては,移動体の最も基本的な物理量である推進速度の最 大化を設定する.

まずはじめに水平面上での滑走を行い,くねり角と推進速度の 関係を実験的に明らかにし，理論と比較する。またこの結果から 推進速度を最大化するくねり角を導出する。

次に傾斜面に応じて,推進速度を最大化するくねり角を適応的 に選択する手法を提案し，実験でその有効性を確認する[7].

\section{1くねり角と推進速度}

体軸方向速度 $V_{s}$ 老一定とし, 〈ねり角 $\alpha$ と推進速度 $V_{x}$ につい て定性的に考察する.

くねり角 $\alpha$ 大゙大きなると接線力が大きくなりその結果体軸方 向への推進力は増加し, 滑らかな滑走が可能となる(式 (5)). し かし 䈏大するに従って行程比は小さくなり，その結果，推進 速度 $V_{X}$ は低下する（式 (4))。したがって推進速度を最大化する ためには，式（7）に示される $\alpha$ の下限值で推進すればよい.

実験は式 (3) で求められる体軸方向速度を $0.1[\mathrm{~m} / \mathrm{s}]$ と固定し, くねり角を变化させたときの実際の滑走速度 $V_{S E}$ を測定する。ま た同時に法線力およびモー夕電流を計測する。次に $V_{S}$ を変化さ せ，同様の測定を繰り返す。測定の範囲は $V_{S}$ がおよそ $0.1[\mathrm{~m} / \mathrm{s}]$ か ら $1.0[\mathrm{~m} / \mathrm{s}]$ まで, くねり角は $12.7[\mathrm{deg}]$ から $89.1[\mathrm{deg}]$ まで変化 させた。

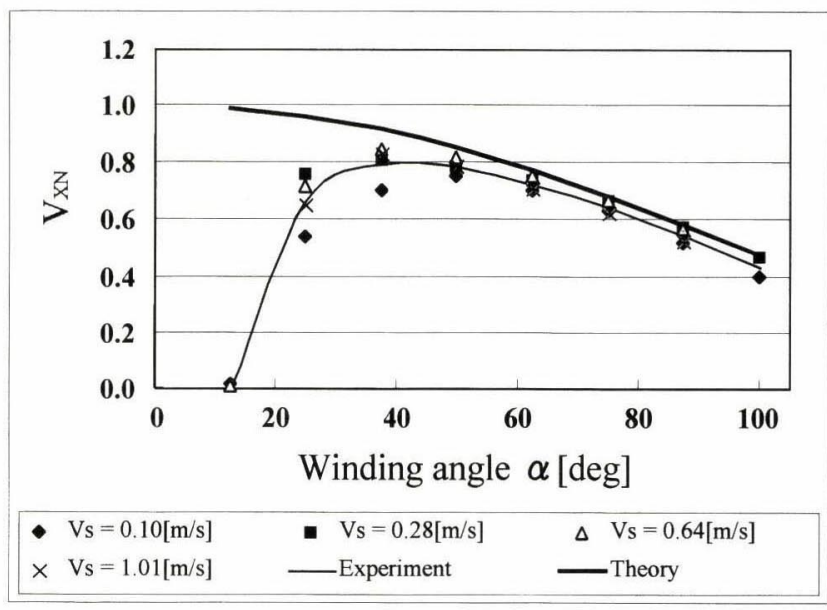

Fig. 10 Winding angle vs. normalized propulsive velocity on flat surface

(a) $\alpha=13^{\circ}$........ Normal force [kgf]

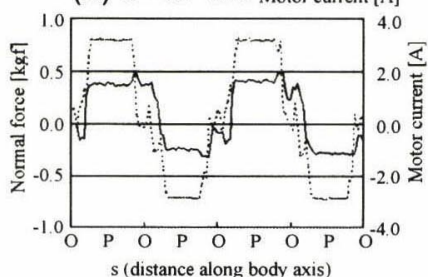

Fig. 11 Distribution map of the normal force

同様の滑走体型で $V_{S}$ のみを变化させて測定を行うことで, $V_{S}$ が 大きくなることにより生ずる慣性力など動力学的な影響を考察す ることができる. 実験結果を検討するため, 得られた $V_{S E} に$ 対し て以下の正規化を行う.

$$
V_{X N}=\frac{V_{S E}}{V_{S}} \cdot \frac{X(l)}{l}
$$

正規化速度 $V_{X N}$ とくねり角 $\alpha$ の関係を Fig. 10 に，また測定さ れた法線力の一例を Fig. 11 (a)(b)に示す.

まず動力学的な影響であるが, 理論滑走速度によらずくねり角 に対して同様の傾向を見せていることから,滑走速度による慣性 力の影響はほとんどないものと考えられる。したがって静力学関 係のみで検討したとしても問題ないことが明らかになった.

次にくねり角と推進速度の関係であるが, $V_{X N}$ の平均值は上に凸 なグラフとなり， $\alpha=43[\mathrm{deg}]$ で最大值となった．

くねり角が大きい領域では理論值とよい一致が見られる。この ときの法線力の分布はFig. 11 (b)のようになり, 理論から求めら れた分布概形とも比較的よく一致する.しかしくねり角 $30[\mathrm{deg}]$ 以下では急激に推進速度が低下していることがわかる.このとき 例えば $\alpha=13$ [deg]の法線力分布はFig. 11 (a)のように台形状に なる。これはハードウェア的な電流制限がアクチュエー夕にか かったためである。またこのとき式（7）に示される滑走可能条 件を十分満たしているにもかかわらず体幹はまったく推進するこ とができなかった。くねり角が小さい領域の理論と実験の不一致 


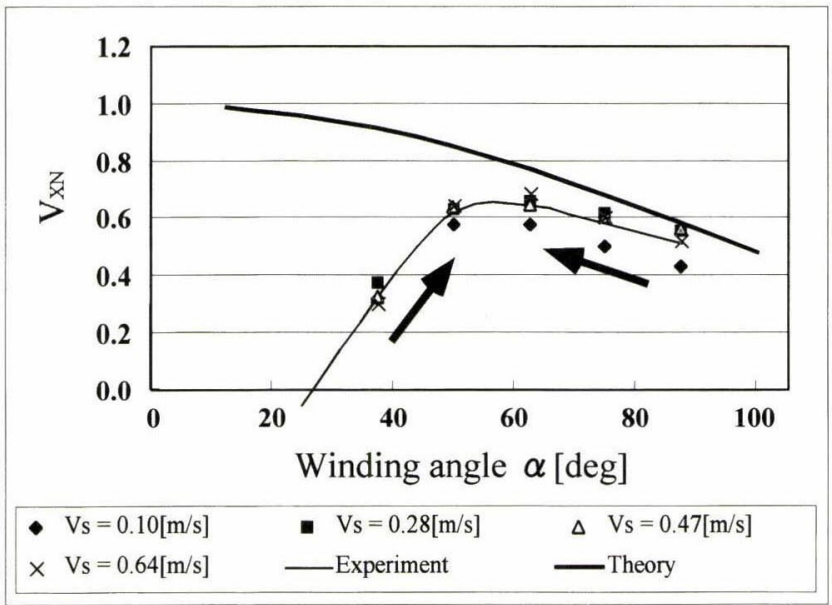

Fig. 12 Winding angle vs. normalized propulsive velocity on sloping surface

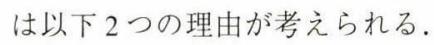

まず機構的な側面として,実験機には節間にバックラッシやサ スペンションによる機構的なガタが存在するため, 小さなくねり 角だ蛇行運動が吸収されてしまい, 有効な推力を発生できない ことが考えられる.

もう一つの理由として解析の仮定との差異が挙げられる.

従来理論においては滑走体型とは無関係に体幹のトルク分布を 仮定し，これに基づいて式（7）が誘導される。しかしながら機 械モデルを実際に制御する場合, 滑走体型とトルク分布は独立に 取ることができず, 相関関倸を持っている.本モデルにおいても 制御しているのは位置のみであり,トルク分布は制御することが できない.よってくねり角が小さくなることによりトルク分布が 変化し,アクチュエータ出力の限界を超えてしまったものと考え られる。

以上の考察からくねり角が小さい領域では実験機のハードウエ ア的制約により推進速度が低下することが明らかになった。また このとき滑走体型とトルク分布を分離して考える従来理論は適用 できないことが明らかになった。より現実を反映するためにはト ルク分布と滑走体型の関連を考慮した解析が必要である.

しかしながら機械モデルの効率的な推進制御法という立場から Fig. 10 をあらためて見ると，実験的に推進速度を最大にするく ねり角が存在するという有用な結果が得られた. 同様の実験を斜 度 4 [deg] の傾斜面上で行い，その結果を Fig. 12 に示す. 水平面 に比して，より大きなくねり角 $(\alpha=56[\mathrm{deg}])$ が最適值となり, 直観とも一致する結果である.

\section{2 くね角の適応推進}

前節の結果を踏まえて, 傾斜面に応じてくねり角を変化させる 対地適応的推進を提案する.

これはくねりの大きさを微少変動させ,推進速度が向上した場 合にはそのくねり角を採用する.すなわち Fig. 12 の矢印で示さ れるようにつねに推進速度を高めるよう漸近的にくねり角を変化 させる方法である.本手法を用いれば摩擦係数比が異なる路面上 を推進する場合でも対応することが可能である.したがって氷上 滑走実験において推進不可能であったエッジ A であっても，本

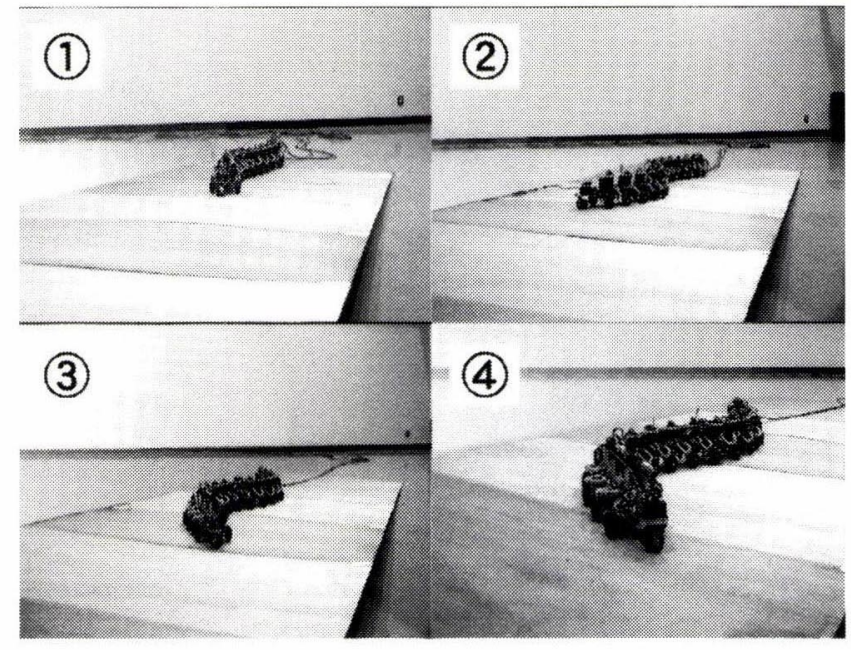

Fig. 13 Terrain adaptive propulsion

制御手法の導入により滑走可能になると考えられる.

本制御則を用いて水平面から傾斜面への登坂実験を行った.初 期に設定したくねり角は20[deg]である。傾斜面に乗り移るとし ばらくは登坂することができず法線方向への横滑りや彴退などが 見られたが, 徐々にくねりを大きくし登坂していく動作が確認さ れた（Fig. 13）.

以上の実験からくねり角を変化させることによる傾斜面への適 応推進が実現されていることがわかる。

\section{7. ま と}

本論文ではへビのほふく推進の工学的応用と機械モデルによる 検証を目的として, 自立索状能動体 ACM-R1 を構築した.

ACM-R1 は以前に構成されたACM III に比して完全自立型と なるだけでなく推進速度もおよそ2倍になり, 著しく高い性能を 示した.実用的なロボット研究においてはそのときの技術環境に 応じたデバイスを用いて常に実際のシステムを構築していくこと が重要であると筆者らは考える。

構成された ACM-R1 を用いて氷上滑走実験を行い, 原理的に 水上でも滑走できることを機械モデルで実証した.

次にくねり角と推進速度の関係を実験的に明らかにし, 理論と の比較を行った、その結果滑走体型とトルク分布を独立に扱う従 来理論が適用できない場合があることを述べた.

さらに推進速度を評価指標として摩擦係数比に応じてくねり角 を適応的に変化させる制御則を提案し,傾斜面への登坂実験によ りその有效性を確認した.

今後の課題としては, 機械モデルにおいては消費エネルギを評 価基準とした滑走の最適化や法線力七ンサの情報を用いた適応滑 走などが挙げられる.また理論的側面では, より機械モデルに適 した滑走理論として屈曲形態に依存したトルク分布をもつ,新た な滑走理論の検討が必要であると思われる。

謝 辞 快く実験の場を提供して下さいました神奈川スケート リンクの皆様に深く感謝いたします.また本研究は文部省科学研 究費 (COE 形成基礎研究費スーパーメカノシステムおよび特別 研究員奨励費）を使用して行われました。 


\section{参 考 文 献}

[1] 広瀬茂男：生物機械工学. 工業調査会, 1987.

[2] 馬: “へビの運動形態に関する研究 (第 1 報：へビの直進蛇行移動体形曲 線) ”, 日本機械学会論文集, 62-593 (C編), pp.230-236, 1996.

[3] 馬・内藤: “蛇型移動ロボットに扔ける蛇行運動の解析”, 日本機械学会口 ボティクス・メカトロニクス講演会'97論文集(Vol.A), pp.391-292, 1997

[4]広瀬, 遠藤 : “完全自律型菜状能動体“ACM-R1”の開発”, 日本機械学会口
ボティクス・メカトロニクス講演会’97論文集（Vol.A），pp.309-310, 1997.

[5]福島・妻木·広瀬: “PWM 制御方式DCサーボモー夕駆動回路の開発”, 第 13 回日本ロボット学会学術講演会予稿集, pp.1153-1154, 1995.

[6] 遠藤・外川・広瀬 : “グライド推進の提案”, 第 16 回日本ロボット学会学 術講演会予稿集, pp.209-210, 1998.

[7] 遠藤・外川 - 広瀬：“索状能動体“ACM-R1”による対地適応推進の研究”, 日本機械学会ロボティクス・メカトロニクス講演会'98 論文集, 1AII 1-3, 1998.

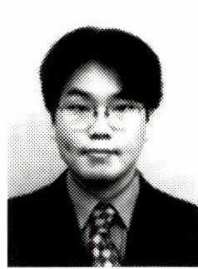

\section{遠藤 玄 (Gen Endo)}

1972 年 10 月 20 日生. 1998 年東京工業大学機械物理工 学専攻博士前期課程修了. 現在, 同専攻博士後期課程 に在籍、ヘビ型移動ロボット, 脚 - 車輪型移動ロボッ トの研究に従事. 1998年より日本学術振興会特別研究 員.

(日本ロボット学会学生:会員)

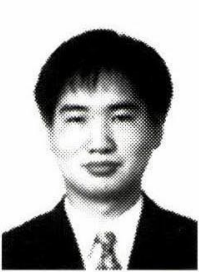

外川圭司（Keiji Togawa）

1975 年 8 月 22 日生. 1998 年東京工業大学機械宁宙学 科卒業. 同年同大学大学院機械物理工学専攻修士課程 進学, 現在に至る。ヘビ型移動ロボット, 脚 - 車輪八 イブリッド移動体の研究に従事.

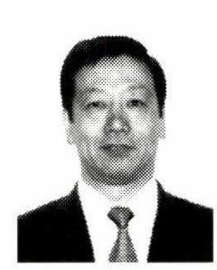

広瀬茂男（Shigeo Hirose）

1947年12月6日生. 1976年東京工業大学制御工学専攻 博士課程修了. 同年, 同大学機械物理工学科助手, 1979 年同大学助教授, 1992年同大学教授, 現在に至る. 口 ボットの機構, センサ, 制御の研究に従事. 工学博士.

(日本ロボット学会正会員) 